\title{
Por que \\ estudamos?
}

\section{RUBENS RODRIGUES TORRES FILHO}

Estudar: esse costume, essa prática, esse vício. Por que afinal temos de sentir-nos atraídos por isso, que parece ser uma espécie de procura, uma busca, uma quête? Que tipo de imagem governa esse ato? O modelo de um escavar? Desenterrar? Ou então: perseguir? Seguir rastros? Ou: "juntar coisa com coisa"? "Ligar os fatos"? Conseqüentemente, montar um quebra-cabeças, encaixar peças?
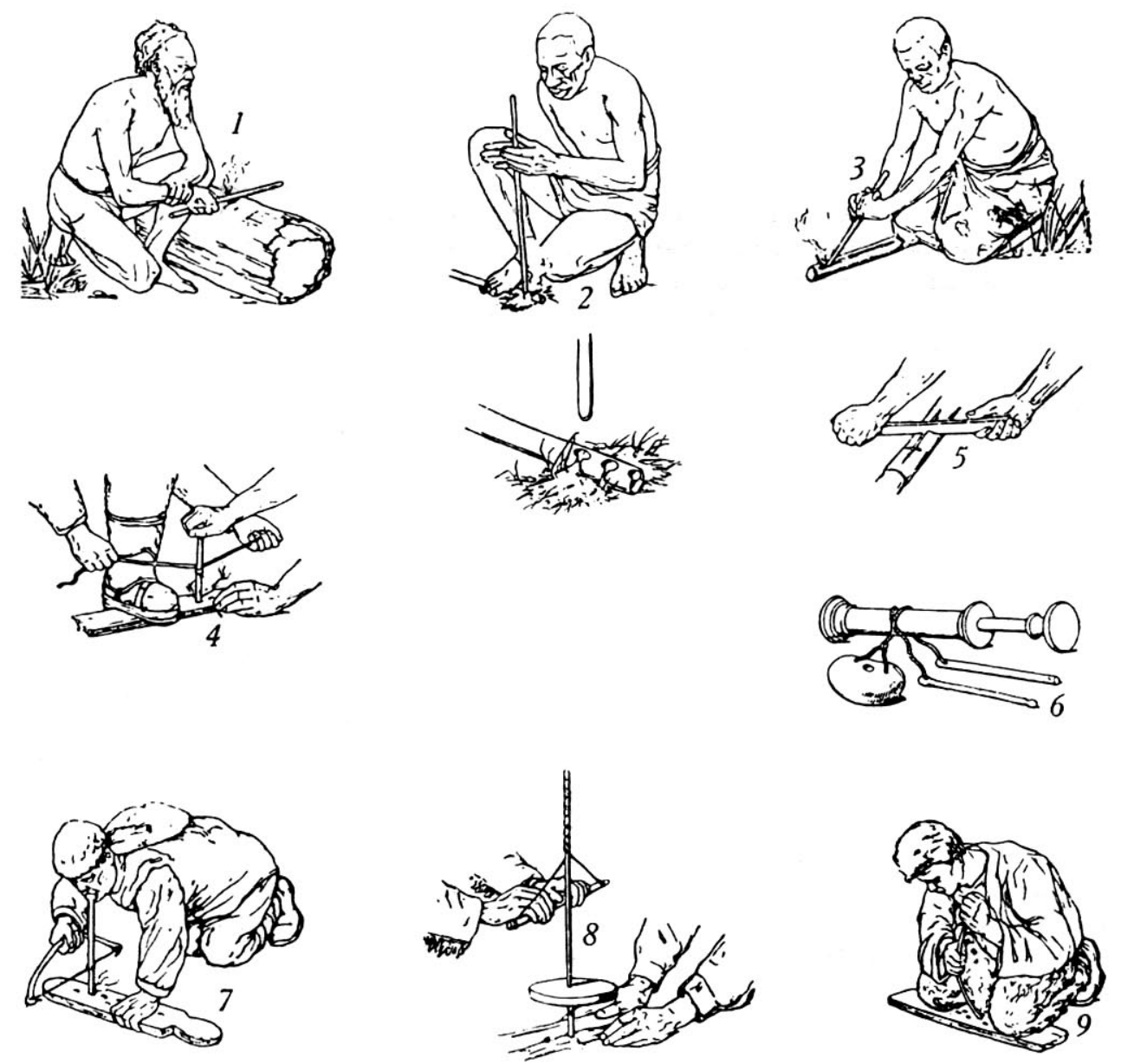

RUBENS RODRIGUES TORRES

FILHO é historiador da filosofia e autor do ensaio $O$ esplrito e a letra. 
Vários tipos de ocupação, entretenimentos variados. Charadas. Passatempos. Jogos de concentração para distrair. Introduzir um sentido no aleatório ou então supor que esse sentido já está lá posto, oculto, e que então alguém o introduziu ali. Esconder algo para que alguém o busque. Esconde-esconde. A verdade que se esconde, o afeto que se encerra ("se esconde" no sentido de "está contido"). Reservas de significação. O que "nos reserva" um texto.

Uma mitologia branca (Derrida) em todas essas imagens, analogias. Orientar-nos por um desses modelos, seguir um desses esquemas como se fosse um mapa. Proceder segundo um imaginário escolhido, determinante e arbitrário. Também uma espécie de cálculo com signos, na relação com o texto (chamar isso de "método", metà hodós?).

Por exemplo, os pares de conceitos, entredefinindo-se por oposição dois a dois: "mecânico" versus "dinâmico". As substituições permitidas, por equação. Permutações. Jogos lógicos. "Lógica" versus "metafísica". Notar que o sentido imediato não é tranqüilo, alçapões de sentido. Mesmo para uma relação descritiva. Um texto e "ação comunicativa" (Habermas)?

As contaminações, o hábito de referir um determinado signo a um contexto especffico e ver nesse signo sempre as marcas desse mesmo contexto. $\mathrm{O}$ "realismo" da querela dos universais: na Idade Média era o contrário de... "nominalismo".

Quando mais profundamente se medita, acreditando mergulhar numa profundeza ideal, mais se perde pé nessa superfície trabalhada por "efeitos de sentido" - a palavra na página, a agilidade desses deslizamentos - mas então será sempre com os poderes do imaginário que essas forças todas estarão jogando? Surge então uma necessidade, não só de pensar - "energia" mental idealista - mas de escrever: pensar com a ponta da caneta, diretamente no papel, sucessão de minúsculos atinhos, retas, curvas, pingos, nas fibras materialistas que sustentam uma a uma esse mover-se, o querer real. Caberia, teria cabimento? Atos de percepção, qualidade perceptiva. Pergunta: - Que sentido tal palavra "pode" ter nesse texto?

Psicologia de um intérprete que se pretendesse "fiel": - Minhas articulações tornaram o texto de Novalis (fragmental) coerente? Ou sua coerência possibilitou a articulação? Esta segunda opinião, objetivista, realista, é sem dúvida a mais atraente, faz de mim um observador atento, mas neutro, e garante a firmeza de minhas afirmações: eu não tinha escolha, afinal, já que objetivamente é assim. Nem é meu ponto de vista, sempre sujeito à revisão, nem mesmo é uma tese que pretendesse demonstrar, meus enunciados a serviço dessa "causa", subordinados a esse desejo. Entendam, pois, meus proferimentos como obedientes ao feitio do seu próprio objeto, curvados ao capricho

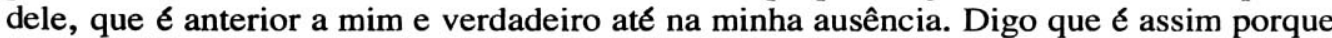
assim é. Detestaria que fosse porque o digo, pois não quero comandar. Fazer minha vontade, no caso, seria o modo mais seguro de contrariar-me.

Uma interpelação do texto ao leitor. O texto em seu leito, deitado. Atividade só por parte do outro, que lhe põe o olho em cima e vai dotando de sentido aquelas combinações de letras (ao todo 24 sinais, separados por espaços), pressupondo apenas a condição de que esses sinais já lhe sejam conhecidos: a alfabetização. Em situações de fala, aparentemente, cabe passividade ao ouvinte, que no entanto tem a mesma função que o leitor: na qualidade de destinatário, receptivo.

Como pode o texto, o fraco, desprovido de entonação, gesticulação, presença, deixar de desenvolver as virtudes reativas descritas por Nietzsche? Chamar sem voz? Ganhar no berro, em silêncio? Paraplégico, imóvel, depende das virtudes cristãs do outro, daquele que se define pelo ato mesmo de atender-lhe, que se chama leitor por ser quem lê. O sinal "atrai" a vista, "prende" o olhar. Mas por que meios, se ele é sinal, inerte?

O leitor talvez acredite estar com ele na mesma relação de neutralidade - de observação - em que se põe perante os fatos da natureza. Julga-o passivo, disponível a seu dispor, e por sua vez dispõe-se a obedecer-lhe. Perseguidor, converteu-se em seguidor. Trompe-l' oeil? Image mise en abime? "Isso" de ler e escrever.

Novalis, que foi historicamente aquele "leitor ativo" solicitado por Fichte, identificou no texto da Wissenschaftslehre uma operação que ele batizou de innere Wunder ("milagre interno") e descreveu-a assim: - "Fichte, com palavras escritas, com formulas, com combinações, opera milagres internos." - Será que o romantismo há de retornar sempre? 